\title{
A hierarchical classification of the Timpanoginae (Ephemeroptera : Ephemerellidae) and description of a new species from Québec
}

\author{
W.P. McCafferty 1
}

Keywords : Ephemeroptera, Ephemerellidae, Timpanoginae, Dentatella, new species, new tribes.

A strictly phylogenetic classification of the supergeneric taxa within the subfamily Timpanoginae includes the Attenellini, $\mathrm{n}$. tribe, consisting of Attenella Edmunds ; the Eurylophellini, n. tribe, consisting of Dentatella Allen, n. stat., and Eurylophella Tiensuu ; and the Timpanogini, $n$. tribe, consisting of Timpanoga Needham and Dannella Edmunds, n. stat. Dentatella danutae McCafferty, $n$. sp., is described from larvae taken from a stream in southern Québec, Canada. The new species differs from the obviously closely related $D$. bartoni (Allen) by possibly striking coloration differences as well as numerous slight structural differences.

Classification hiérarchique des Timpanoginae (Ephemeroptera : Ephemerellidae) et description d'une espèce nouvelle du Québec

Mots-clés : Ephemeroptera, Ephemerellidae, Timpanoginae, Dentatella, espèce nouvelle, tribus nouvelles.

Une classification strictement phylogénétique des taxons supergénériques à l'intérieur de la sous-famille des Timpanoginae inclut : les Attenellini, n. tribu, consistant en Attenella Edmunds ; les Eurylophellini, n. tribu, comprenant Dentatella Allen, n. stat., et Eurylophella Tiensuu ; et les Timpanogini, n. tribu, comprenant Timpanoga Needham et Dannella Edmunds, n. stat. Dentatella danutae McCafferty, n. sp. est décrite à partir de larves provenant d'un cours d'eau du Sud Québec, Canada. L'espèce. nouvelle diffère de la très voisine $D$. bartoni (Allen) par de possibles différences frappantes sur la coloration, ainsi que par de nombreuses légères différences de structure.

\section{Introduction}

The Holarctic, but primarily North American, subfamily Teloganodinae of the Holarctic and Oriental family Ephemerellidae was clearly delineated by McCafferty \& Wang (2000) within a cladistic framework and strictly phylogenetic classification of the mayfly infraorder Pannota. The subfamily is essentially equivalent to what Allen (1984) had initially recognized as the subtribe Timpanogae, and what was subsequently cladistically analyzed in detail as the Timpanoga complex of genera by McCafferty \& Wang

1. Department of Entomology, Purdue University, West Lafayette, IN 47907, USA.
(1994). All genera recognized in the subfamily Timpanoginae herein have been known at one time as subgenera (Edmunds 1959). Timpanoginae lack both gills 2 and 3 as larvae and gills 2 and 3 remnants as alate stages. This differentiates them from other Ephemerellidae (Ephemerellinae s.s.), which lack gills 2 as larvae and remnants of such as alate stages but retain gills 3 as larvae and remnants of such as alate stages.

McCafferty \& Wang (1994) did not know at the time of their study to what hierarchical taxonomic rank the Timpanoga complex of genera would eventually reside, once all major lineages of Pannota could be studied comparatively. As a result they were forced to take a relatively conservative approach in recognizing genera within the complex while maintaining a strictly phylogenetic classification. As such, McCafferty \& Wang (1994) recognized only the genera Attenella Edmunds; 
Eurylophella Tiensuu, and Timpanoga Needham. Based on cladistic relationships, what had for a brief time been the genus Dannella Edmunds was placed as a subgenus within Timpanoga, and the subgenus Dentatella Allen was placed under the genus Eurylophella. In addition, the genera Eurylophella and Timpanoga were shown to be sister genera whose common stem had branched more basally with the Attenella lineage. Evidentiary data for these relationships as well as species relationships within Attenella and Dannella may be found in McCafferty $(1977,1978)$ and McCafferty \& Wang (1994). Other than the sister relationship of subgenera Dentatella and Eurylophella s.s. within Eurylophella, the precise species relationships within $E u$ rylophella s.s. remain unknown, although concepts of the Eastern North American species of the latter have been recently revised by Funk \& Sweeney (1994).

The current generic classification of the Timpanoginae certainly could be maintained as is. However, because the grouping of genera and subgenera has been shown to represent a phyletic subfamily (McCafferty $\&$ Wang 2000), there are now other options available for a higher classification within the grouping. If one were to consider the level of differentiation of genera in the subfamily Ephemerellinae at the present, together with the distinctiveness of the subgenera within Timpanoginae [see discussion and key to genera and subgenera in McCafferty \& Wang (1994)], it could be argued that those subgenera should be given full generic status. For example, although the subgenera Timpanoga and Dannella are clearly sister groups, they are also highly distinctive from each other. In the same respect, Dentatella and Eurylophella are also distinctive.

In keeping with a completely phylogenetic classification and because of the constraints that cannot be overcome by sequencing conventions as applied to genera in this case (Nelson 1972, 1973 ; Wiley 1981), full generic classification of the above lineages of Timpanoginae can be attained only if an additional infracategory is sequentially incorporated into the classificatory scheme of the subfamily. Because I believe it is meaningful to recognize these lineages at the generic level, I propose the following higher hierarchical classification of the Timpanoginae. I also describe a new species of one of the taxa given new generic status herein. The cladistic relationships of all superspecific taxa within the new classification of the Timpanoginae can be precisely generated from the linear classification.

\section{Revised higher classification}

\author{
Subfamily Timpanoginae \\ Tribe Attenellini, n. tribe \\ Genus Attenella \\ Tribe Eurylophellini, n. tribe \\ Genus Dentatella, n. stat. \\ Genus Eurylophella \\ Tribe Timpanogini, n. tribe \\ Genus Timpanoga \\ Genus Dannella, n. stat.
}

\section{New combinations}

The new hierarchical classification results in the following new combinations : Dentatella bartoni (Allen), n. comb. ; Dannella lita (Burks), n. comb. ; Dannella provonshai (McCafferty), n. comb. ; and Dannella simplex (McDunnough), n. comb.

\section{Dentatella danutae McCafferty, n. sp.}

\section{- Description}

\section{Larva}

Body : Overall shape short, broad, and dorsoventally flattened. Length $5.0 \mathrm{~mm}$ (middle instar to somewhat older). General coloration dark brown with lighter markings dorsally, pale brown ventrally.

Head : Vertex and frons generally granular brown. Antennal flagella light. Maxillae without palpi.

Thorax : Notum dark brown, mottled with lighter shades of brown. Legs patterned as in Figure 1; tibiae and tarsi with light, surrounding bands basally and distally ; femora with light apex. Forefemora (Fig. 1) with dorsal transverse band of setae extending basally to approximately basal one-fourth of femur. Hindfemora (Fig. 1) with posterior (dorsal) edge more or less evenly convex. Claws with 3-5 minute denticles marginally.

Abdomen : Dorsal abdominal length to width ratio 1.1. Terga generally patterned as in Figure 1 ; terga 57 with paired submedian tubercles. Segments 2-9 with well-developed posterolateral projections ; projections of tergum 8 nearly reaching posteriorly level of those of tergum 9. Fingerlike gills 1 long and clearly inserted dorsally on tergum 1 . Operculate gills very large and obovate, reaching tergum 9 , covering all subsequent abdominal gills. Caudal filaments pale, light brown at extreme base and with light brown, broad annulations over most of length. 


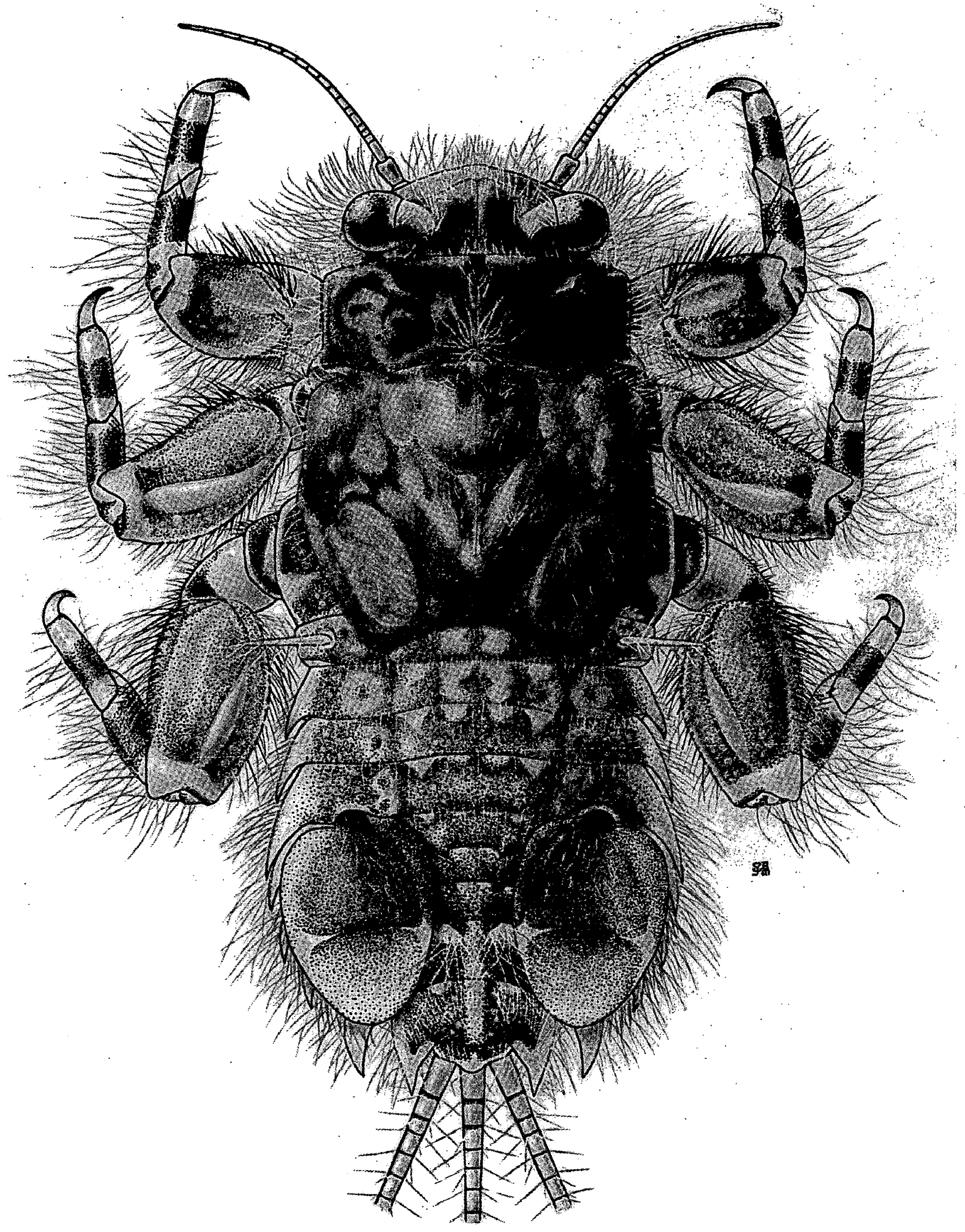

Fig. 1. Dentatella danutae, dorsal habitus of male larva.

Fig. 1. Dentatella danutae, habitus dorsal de larve mâle. 


\section{Adult}

Unknown.

\section{- Material examined}

Holotype : Larva, Canada, Québec, Rivière-duLoup, Latitude 4743.74 North, Longitude 6931.51 West, 12-October-1999, deposited in the Purdue Entomological Research Collection (PERC), West Lafayette, Indiana, USA. Paratypes : one larva, Canada, Québec, Rivière-du-Loup, Latitude 47 49.32, Longitude 69 31.17, 10-October-1999 (PERC); one larva, same data and deposition as previous, except longitude 69 31.33. Other material: two larvae (not examined), from the Rivière-du-Loup, deposited in personal collection of D. Zaranko (Guelph, Ontario). Additionally, larval material of Dentatella bartoni from Howdendale, Ontario, 29-May-1974, D. R. Barton (PERC) were comparatively studied.

\section{- Etymology}

The species is named in honor of Danuta Zaranko.

\section{- Diagnosis}

Dentatella danutae is only the second species to be described of Dentatella, and therefore needs be only compared with $D$. bartoni at this time. Structurally the two species are very similar, despite the impression that Figures 2 and 3 of Allen (1977) imparts. For example, it would appear that the operculate gills of the two species were very different if one compares Allen's figures with Figure 1 herein. However, study of $D$. bartoni has revealed that the operculate gills of this latter species are essentially as well developed as those here described and illustrated for $D$. danutae. Also from Allen's figure, it would appear that gills 1 are inserted dorsolaterally on tergum 1 ; however, I found them dorsally inserted similar to those of $D$. danutae. On the other hand, although Allen (1977) stated that claw denticles ranged from six to seven in number, his Figure 2 shows only five denticles, which would overlap with the three to five (usually four) that I found in $D$. danutae. The claws of $D$. bartoni that I inspected, however, agreed with Allen's written description, and I therefore must regard the number drawn by Allen to be incorrectly represented, as were the gills.

Given the corrections to Allen's figures as mentioned above, there remains the possible difference in claw denticle number. This may or may not hold when more material becomes known, because a larger range of variability is sometimes found in this character in other Ephemerellidae species. The posterior development of the abdominal posterolateral processes appears greater in $D$. danutae than in $D$. bartoni, but again this may vary somewhat with age and may prove to be unreliable. When the dorsal abdominal length to width ratios found in the larvae of the two species are compared, it can be seen that $D$. danutae is 1.1 (nearly as wide as long) and that of $D$. bartoni is 1.4 (close to one and one-half as long as wide). More specimens and age classes will be needed to test the stability of this possibly significant difference.

Some differences I found with respect to the femora appear more likely to be stable and of use in differentiating the larvae of the two species. In the forefemora of $D$. danutae, the dorsal transverse band of setae (and thus the raised shank of the femur) reaches considerably further basally than it does in $D$. bartoni (to the basal one-fourth in $D$. danutae vs. to between the basal one-half to one-third in $D$. bartoni). Additionally, the hindfemora of $D$. danutae is more or less evenly rounded-convex along the entire posterior edge, whereas that margin in $D$. bartoni is convex only in the distal half.

The most obvious apparent difference is in the coloration of $D$. danutae compared with that of $D$. bartoni. Allen was correct in describing $D$. bartoni as yellow to light brown. The material of $D$. bartoni material that I have examined is more or less entirely yellow. All of the $D$. danutae are dark brown with distinct whitish markings. In $D$. bartoni, there is no indication or suggestion of the striking leg markings that are so representative of the larvae of $D$. danutae. There is a slight indication of sublateral darkening on the dorsum and venter of the abdomen of $D$. bartoni, but not the detailed tergal markings found in $D$. danutae. I did find some similar markings in the two, however, in that there are two narrow dark rings basally on each of the caudal filaments. The rings appear further apart in $D$. bartoni.

Although it could be argued that differences detailed above are indicative of variability within the same species, rather than species differences, only time will tell as more material and the adult stages becomes available. The same argument could be given for many of the sister species within Ephemerellidae and Ephemeroptera in general. For example, the larvae of the species of Dannella (also Timpanoginae) would appear much less distinguishable than the two Dentatella species under discussion. I believe it is appropriate to recognize the new species based on the available data. Additionally, there could possibly be some habitat differences between $D$. danutae and $D$. bartoni, as discussed below.

- Discussion

Dentatella danutae was taken in lotic habitats of the Canadian province of Québec in the vicinity of the 
Notre Dame Mountains east of the St. Lawrence River and just north of the northwestern tip of the USA state of Maine. This brings the total of mayfly species now known from Québec to 164 (see McCafferty \& Randolph 1998). The species will quite possibly eventually be found in the northern region of New England in the USA. Dentatella bartoni is also known only from larvae and only from Canada (Ontario), but has been found only from wave-swept lentic habitats of Lake Huron and Georgian Bay (Barton \& Hynes 1978). It should be pointed out, however, that most mayfly species that have been taken on the wave swept shores of the Great Lakes are species that are typically associated with lotic habitats.

The Rivière-du-Loup at sites where the new species was collected ranges from 30 to $40 \mathrm{~m}$ in width. Larvae were found on mixed substrate consisting of sand ranging to cobble (with apparently very little if any silt), at a water depth of 0.15 to $0.5 \mathrm{~m}$, a surface current velocity of 0.1 to $0.6 \mathrm{~m} / \mathrm{s}$, and a temperature ranging from 10 to $13 \mathrm{C}$. More detailed observations of the biotope with which the larvae were associated are not available.

\section{Acknowledgements}

I would like to thank D. Zaranko (Guelph, Ontario) for bringing materials to my attention and her donation of specimens to PERC ; L. Sun (West Lafayette, Indiana) for his rendering of the habitus figure ; A. Thomas (Toulouse, France) for aiding with the French translation of the abstract and handling of the manuscript ; and D. Barton (Waterloo, Ontario) for the donation of materials to PERC. Research was supported by U. S. National Science Foundation Grant DEB-9901577. This article has been assigned Purdue Agricultural Research Program Journal No. 16284.
}

\section{References}

Allen R.K. 1977. - A review of Ephemerella (Dannella) and the description of a new species. Pan-Pac. Entomol., 53 : 215-217.

Allen R.K. 1984. - A new classification of the subfamily Ephemerellinae and the description of a new genus. Pan-Pac. Entomol., $60: 245-247$.

Barton D.R. \& Hynes H.B.N. 1978. - Wave-zone macroinvertebrates of the exposed Canadian shores of the St. Lawrence Great Lakes. Internat. Assoc. Great Lakes Res., $4: 27-45$.

Edmunds G.F. 1959. - Subgeneric groups within the mayfly genus Ephemerella (Ephemeroptera : Ephemerellidae). Ann. entomol. Soc. Am., 52 : 543-547.

Funk D.H. \& Sweeney B.W. 1994. - The larvae of eastern North American Eurylophella Tiensuu (Ephemeroptera : Ephemerellidae). Trans. Am entomol. Soc., $120: 209-286$.

McCafferty W.P. 1977. - Biosystematics of Dannella and related subgenera of Ephemerella (Ephemeroptera : Ephemerellidae). Ann. entomol. Soc. Am., 70 : 881-889.

McCafferty W.P. 1978. - A natural subgeneric classification of Ephemerella bartoni and related species (Ephemeroptera : Ephemerellidae). Great Lakes Entomol., 11 : 137-138.

McCafferty W.P. \& Randolph R.P. 1998. - Canada mayflies : a faunistic compendium. Proc. entomol. Soc. Ontario, $129: 47-97$.

McCafferty W.P. \& Wang T.-Q. 1994. - Phylogenetics and the classification of the Timpanoga complex (Ephemeroptera : Ephemerellidae). J. N. Am. benthol. Soc., $13: 569-579$.

McCafferty W.P. \& Wang T.-Q. 2000. - Phylogenetic systematics of the major lineages of pannote mayflies (Ephemeroptera : Pannota). Trans. Am. entomol. Soc., $126: 9-101$.

Nelson G.J. 1972. - Phylogenetic relationships and classification. Syst. Zool., $21:$ 227-231.

Nelson G.J. 1973. - Classification as an expression of phylogenetic relationships. Syst. Zool., 22 : 344-359.

Wiley E.O. 1981. - Phylogenetics : the theory and practice of phylogenetic systematics. Wiley, New York. 